Matko Matija Marušić (Zagreb)

\title{
Verses of Faith and Devotion. Seeing, Reading, and Touching Monumental Crucifixes with INSCRIPTIONS $\left(12^{\mathrm{TH}}-13^{\mathrm{TH}} \text { CENTURY }\right)^{*}$
}

$\mathrm{If}_{\mathrm{a}}$ we want to sketch the general iconographical and compositional scheme of the late medieval monumental crucifixes, we observe that the earliest surviving examples display Living Christ and the scenes of the Passion, the Entombment, and the Resurrection, depicted in ordered narratives and flanking the centrallypositioned Crucified. The initial decades of the $13^{\text {th }}$ century saw the emergence of new iconography, the Suffering Christ, as well as the introduction of a much simplified form of these large-scale painted images. Thenceforth, historiated crosses were replaced by crucifixes customary equipped with the bust-length figures of Virgin Mary on the Christ's right, and John the Evangelist on the left terminal of the cross. While the text was normally limited to titulus crucis containing the INRI acronym, in some cases the imagery was supported by a more elaborate textual interpretation in form of a verse inscription running on the horizontal arm of the cross. As far as crucifixes supplied with inscriptions are concerned, both imagery and text have to be examined as they formed two poles of the communication of the Passion to the devout beholder praying before a crucifix.

The interplay of text and imagery on crucifixes has recently been studied by H.L. Kessler. Kessler's insight is particularly important because he drew attention to inscriptions as distinctive features of some $12^{\text {th }}$-century crucifixes. According to Kessler, "inscriptions not only articulate the meaning of the imagery but also bear on the use(s) in liturgical and private spaces"1. Focusing his attention on the Rosano cross (ca. 1130-1150), and its inscriptions under the smaller narrative scenes, he has convincingly shown how such objects were intended for communal or personal meditation on the Passion of Christ ${ }^{2}$. Moreover, the analysis

\footnotetext{
* This paper grew out of a presentation entitled "Monumental Crucifixes and the Text-Image-Text Strategies of Communicating of Passion," delivered at the "Text Versus a Piece of Art" conference held in Łódź in May 2015. I have benefited greatly from several discussions on the topic of my research with Marco Collareta, a professor of medieval art at the University of Pisa.

${ }^{1}$ H.L. Kessler, Inscriptions on Painted Crosses and the Spaces of Personal and Communal Meditation, [in:] Inscriptions in Liturgical Spaces [= AAAHP 24], ed. K.B. AavitsLand, T. Karlsen Seim, Rome 2011, p. 161.

${ }^{2}$ Ibidem, p. 167, 178.
} 
of verse inscription and their function, combined with the imagery they support, has led him to conclusion on the issue of the original location of crucifixes. Contrary to predominant opinion in the existing scholarship, Kessler argues that suchlike crucifixes were not designed to be hung in the triumphal arches or above the rood screens. The function of verses and the comprehensive narrative of Passion determined the placement of objects, concludes Kessler, given that both text and detailed imagery had to be positioned near the viewer in order to be visible 3 .

The issue here briefly outlined may seem to fall under the text-versus-image problem, but it would be a simplification to represent it exclusively in these terms. The study of inscriptions on devotional objects to some extent differs from the approach to the text-image relations in manuscripts or prayer books. Nevertheless two poles in communication of Passion, imagery and text have to be looked upon as aspects of a much broader question of devotional practices performed before crucifixes with inscriptions. When crucifixes are desacralized and decontextualized in museum collections, cleared away from their native environment which do not exist anymore or have radically changed over time, it does seem as if we are addressing the image-supported-by-text problem. However, if we perceive them as objects placed in richly decorated church interiors, furnished not only with images, lights, colours and inscriptions, but also filled with sounds, smells, and, most importantly, medieval devotees, the broader view of the problem becomes evident.

This necessary multifaceted approach was underlined by M. Mostert who argued how the "reading of an image has to be looked upon together with 'reading' of the church building"4. A devotional object in liturgical space was never autonomous and its contextualisation in research is thus fundamental. In the field of research of text within liturgical spaces, S. Riccioni has very recently adopted an approach designated as "epiconografia", a combination of studies in iconography and epigraphy ${ }^{5}$. The method proposed by Riccioni insists on research of inscriptions combined with the study of relation between text, inscriptions, and imagery. Although here I do not intend to offer an extensive text-based study, but rather seek to place these objects in devotional and liturgical framework by examining their function, I will follow the guidelines proposed by Riccioni, departing from the starting point so clearly articulated by Mostert.

\footnotetext{
${ }^{3}$ Ibidem, p. 178.

${ }^{4}$ M. Mostert, Reading Images and Text: Some Preliminary Observations Instead of An Introduction, [in:] Reading Images and Texts. Medieval Images and Texts as Forms of Communication: Papers from the Third Utrecht Symposium on Medieval Literacy, Utrecht, 7-9 December 2000, ed. M. Hageman, M. Mostert, Turnhout 2005, p. 6.

${ }^{5}$ S. Riccioni S., La Croce in Rosano oltre il Lazio e la Toscana. Riflessi 'europei' della 'riforma gregoriana', [in:] La pittura su tavola del secolo XII. Riconsiderazioni e nuove acquisizioni a seguito del restauro della Croce di Rossano, ed. C. Frosinini, G. Wolf, A. Monciatti, Firenze 2012, p. 119; cf. also Idem, Epigrafia, spazio liturgico e Riforma gregoriana, un paradigma: il programma di esposizione grafica di Santa Maria in Cosmedin a Roma, HAM 6, 2000, p. 143-156.
} 
In aiming to do so, this paper will examine a group of $13^{\text {th }}$-century crucifixes from modern-day Croatia and Italy with particular attention dedicated to three crucifixes from Zadar. They offer an interesting insight into the topic but, as so far, only limited scholarly attention was dedicated to their inscriptions as well as to their devotional context. Following Kessler's observations, along with the problem of relation between imagery and text, main questions arise: What is that sets apart crucifixes supplied by inscriptions from other crucifixes? Was their use in devotional performance different or alike in comparison to other devotional objects, primarily crucifixes without inscriptions? Consequently, did the original location of crucifixes in question differ from other sacred objects in liturgical space? In addressing these inquiries I will analyse inscriptions, confront them with the imagery, and then focus on their performativity and original setting.

\section{Devotion through Inscription}

Prior to starting a case-by-case discussion, a brief remark should be made upon the frequency of inscriptions on crucifixes in the Late Middle Ages. The titulus crucis above the head of Christ was conventional, and usually the solely written text present on crucifixes. The inscription "Jesus of Nazareth, the King of the Jews," or the INRI abbreviation, derives from the Gospel of John according to which the message was trilingual, written in Greek, Latin, and Hebrew ${ }^{6}$. My prime concern, however, are unorthodox, longer and much intricate forms of writing. Judging by the number of survived examples, only a handful of which contain an additional text, inscriptions on crosses were not a frequent phenomenon. Even though their number is relatively small, it is important to point out to the variety of the text inscribed, roughly subdivided in tituli, dedicatory, votive, and devotional inscriptions. In every case they stood for much more than words inscribed or painted ${ }^{7}$.

Of special interest for the topic under discussion are devotional inscriptions. According to the usual typology, they fall under the category of "sacred epigrams /inscriptions". By defining them "devotional" their function and use as a text intended for the beholder praying beneath a crucifix is underlined. When reading the inscription, churchgoers were not informed on the commissioner of the work or the master who executed it, the date of consecration of the altar where it could have been exhibited, nor was the verse explanatory in a sense that described a certain depicted scene. As will be discussed, this type of text triggered a specific pious performance.

${ }^{6}$ P. Tнову, Le Crucifix des Origines au Concile de Trente: étude iconographique, Nantes 1959, p. 7.

${ }^{7} \mathrm{~A}$. Rнову, The meaning of inscriptions for the early and middle Byzantine culture. Remarks on the interaction of word, image and beholder, [in:] Scrivere e leggere nell alto Medioevo: Spoleto, 28 aprile - 4 maggio 2011, Spoleto 2012, p. 731-753.

${ }^{8}$ G. Scala, Le epigrafi, [in:] Lo spazio letterario del Medioevo, vol. 2: La circolazione del testo, ed. G. Cavallo, C. Leonardi, E. Menestò, Roma-Salerno 1994, p. 411. 
What is important to keep in mind is that the medieval response to the written text displayed in public was fundamentally different to the modern one. While today we generally read in silence, our medieval predecessors would have done it audibly ${ }^{9}$. The inscriptions on crucifixes were written horizontally, regularly located beneath the arms of Christ, running parallel to them, and were split in two by the body of the Crucified. The strongest evidence for oral performance of the verses is their metrical structure. All of them are composed in the form of leonine verses with rhyme between the middle and the end of the line. Internal rhyme in the verse originates from medieval practices of reading developed in monastic contexts. Together with the repetition of words, asserted Bernard of Clairvaux, its main purpose was to make the pronunciation easier and to help the devotees to memorise the text ${ }^{10}$. Double rimmed verses can also be found on numerous late medieval church portals, facades, narrative fresco cycles, and altars ${ }^{11}$. In the world of limited literacy their form surely contributed to the easier comprehension of the written word.

Two of the earliest surviving historiated crosses, Guillelmo's cross in Sarzana (1138) and the Rosano cross (ca. 1130-1150), contain verses under every single narrative scene. Verses on the former have been very recently studied by T. Gramigni $^{12}$, while the inscriptions on the latter were subject of aforementioned seminal studies on epigraphy and interrelationship of imagery and text on crucifixes. The author of the Rosano verses was Hildebert of Lavardin (1056-1133) ${ }^{13}$. The text merged with the imagery was not composed for this purpose, but faithfully applied onto the object, as was characteristic for the early and central middle ages. As has been underscored above, in the course of the same century emerged a much simpler type of crucifixes. The viewer's attention was focused to the crucified Christ and Mary and John, while inscriptions articulated messages related to the Crucifixion, occasionally referring to the supplicants, and, as will be discussed, to the devotee who venerated the object.

\footnotetext{
${ }^{9}$ A. Papalexandrou, Text in Context: Eloquent Monuments and the Byzantine Beholder, W\&I 17/3, 2001, p. 261. For development of the silent reading cf.: P. SAENGER, Space Between Words: the Origins of Silent Reading, Stanford 2000.

${ }^{10} \mathrm{~K}$. Ambrose, Visual poetics of the Cluny hemicycle capital inscriptions, W\&I 20/2, 2004, p. 161.

${ }^{11}$ Cf. C.B. Kendall, The Allegory of the Church: Romanesque Portals and Their Verse Inscriptions, Toronto 1998; IDEM, The Gate of Heaven and the Fountain of Life: Speech-Act Theory and Portal Inscriptions, EMS 10, 1993, p. 112-115; R. FAVREAU, Fonctions des inscriptions au moyen âge, CCM 32, 1989, p. 225-226. On the Eastern Adriatic there is a very interesting example of two leonine verses below the cross in the center of the interior portal of the Trogir cathedral, I. BABIĆ, Unutarnja strana lunete glavnog portala trogirske katedrale - djelo majstora Radovana, ShP III/21, 1991, p. 232.

${ }^{12}$ T. Gramigni, Le iscrizioni della croce di Sarzana e le scritture d'apparato toscane del XII secolo, [in:] Scrittura epigrafica e scrittura libraria: fra Occidente e Oriente, ed. M. MANIACI, P. OrsinI, Cassino 2015, p. 133-174.

${ }^{13}$ H.L. Kessler, The French connection: word and image on the Rosano cross, [in:] La pittura su tavola..., p. 133-134.
} 
Let us take for example the crucifix from the Franciscan church of Santa Maria Gloriosa in Venice. This large late $13^{\text {th }}$-century painted cross was remodelled in the course of the time and the secondary figures, most likely included in the original design, were cut off ${ }^{14}$. On the transverse limb two verse inscriptions with Leonine rhyme were discovered during the restoration in 1992:

\section{+IN CRUCE MOSTRAVIT QUANTUM TE GRATIS AMAVIT / PRO MUNDI VITA SUAM CRUCIFIXIT ITA}

(On the cross He has showed how He loved you gratuitous / For the life of the World, He crucified His in this way $)^{15}$

The most distinctive characteristic of these verses is a clear reference to the devotee, and as such they can be rightfully defined as devotional. C. Corsato described their function as a "reminder to the faithful" which needs to be viewed in the context of Franciscan church where the crucifix had been placed ${ }^{16}$. The setting of verses, moreover, is inseparable from the effigy of Christ. When reading the inscription one was led to simultaneous meditation on the meaning of the verse and imagery. While it can be argued that on some crucifixes here quoted the inscriptions are not so prominently placed or are smaller in scale, the three Zadar crucifixes amply illustrate the point of the prominently placed text certainly used in devotional performance.

\section{Performativity of Verse Inscriptions on Zadar Crucifixes}

Monumental crucifixes from the Benedictine nunnery of Saint Mary, Collection of the Franciscan friary and the church of Saint Michael are among the earliest in the East Adriatic, and all display Latin verses beneath or above the arms of $\mathrm{Christ}^{17}$. They are all included in the pioneer study on painted crosses, published in 1929 by E. Sandberg Vavalà, ${ }^{18}$ and later in the comprehensive index of the Romanesque panel painting by E.B. Garrison ${ }^{19}$. With no signature and date,

\footnotetext{
${ }^{14}$ A. Augusti, Un crocifisso duecentesco ai Frari, VenA 7, 1993, p. 155. The Frari crucifix is attributed to the so-called Maestro della Cappella Dotto, C. Santini, Un'antologia pittorica del primo Trecento nella Chiesa di San Francesco a Udine, ArtC 82/762, 1994, p. 187, 195 (n. 8).

${ }^{15}$ A. Augusti, Un crocifisso..., p. 155 (n. 18).

${ }^{16}$ C. Consato, Public Piety and Private Devotion: The Altar of the Cross, Titian and the Scuola della Passione at the Frari, [in:] Santa Maria Gloriosa dei Frari: Immagini di Devozione, Spazi della Fede I Devotional Spaces, Images of Piety, ed. C. Corsato, D. Howard, Padova 2015, p. 103-104.

${ }^{17}$ G. Gamulin, The Painted Crucifixes in Croatia, trans. E. Elias Bursać, Zagreb 1983, p. 13-14; N. Klaić - I. Petriciolli, Zadar u srednjem vijeku do 1409. godine, Zadar 1976, p. 268-269.

${ }^{18}$ E. SAndberg Vavalà, La croce dipinta italiana e l'iconografia della passione, Verona 1929.

${ }^{19}$ All are included in the group of "crucifixes of simple shape" due to their outlines. E.B. Garrison, Italian Romanesque Panel Painting. An Illustrated Index, Florence 1949, p. 177, 180.
} 
the major obstacle in their research is the lack of archival material and any indication not only on their original context, but also on their subsequent histories. Virtually nothing is known on how they found their way to collections and churches where they are treasured today. The full recreation of their original spatial context will therefore not be possible, which by no means should hamper us to investigate the response they evoked from their audience, and the "synthesis between object and environment" 20 .

Despite these obstacles, art historians have dedicated numerous studies to questions of formal patterning, aesthetic qualities, and their stylistic kinship ${ }^{21}$. All these features were closely examined in the context of the eastern Adriatic medieval art, mostly in occasion of important exhibitions held over the last few decades. However, the palaeographical features of verses were not studied and thus have yet to be brought together in a critical study. The analysis of the epigraphical and palaeographical features of inscriptions in order to establish the precise time of execution of crucifixes was in the focus of earlier scholars of the Zadar crucifixes, but recently has not gained special interest ${ }^{22}$. Comparatively little attention was devoted to the (inter)-relation between the text and imagery, primarily because inscriptions were understood only as an additional message to the Passion of the crucified Christ. My aim here is to investigate different strategies of communicating the Passion through these objects starting from the type of text used to support the image of Christ.

The most important crucifix to answer the questions raised no longer survives. Probably manufactured around the middle of the $13^{\text {th }}$-century, it was destroyed in the WW II during the bombing of Zadar. On the transverse limb of the cross two inscriptions were displayed, above and under the arms of Christ respectively, as is visible on the photograph taken prior to its destruction. The lower one consisted of capital letters, while the letters on the upper exhibited characteristics of the minuscule Gothic script. Moreover, the numerous contractions of the words were necessary to write the thirteen-word long text on the upper part of the arm. Both different epigraphy and heavily abbreviated text indicate how the upper inscription was etched onto the crucifix after the lower inscription. In this context

\footnotetext{
${ }^{20}$ B. Williamson, Altarpieces, Liturgy, Devotion, Spe 79/2, 2004, p. 405.

${ }^{21}$ Particular attention was dedicated to their stylistic origin and the "Byzantinizing" characteristics. For the most recent overview of scholarship cf.: E. Hilje, Cat. No. 15 Nepoznati majstor. Slikano raspelo; XII./XIII. stoljeće; Cat. No. 16 Zadarski majstor (?). Slikano raspelo; XIII. stoljeće; and Cat. No. 17 Zadarski majstor (?). Slikano raspelo; XIII. stoljeće, [in:] E. HILJE - R. Tomić, Slikarstvo: umjetnička baština Zadarske nadbiskupije, Zadar 2006, p. 92-99 (with further references); I. Fisković, Crucifixion with the Living Christ, $12^{\text {th }} / 13^{\text {th }}$ c., [in:] The Croats: Christianity, Culture, Art: Exhibition Catalogue, Musei Vaticani 1990-2000, Zagreb 1999, p. 438, 440; IDEM, Romaničko slikarstvo u Hrvatskoj, Zagreb 1987, p. 50-51; G. GAmulin, The painted crucifixes..., p. 13-17, 115- 116.

${ }^{22}$ Many of conclusions have been discredited. In the first place the datation of crucifixes to the $9^{\text {th }}$ and $11^{\text {th }}$ century. Cf. G. Gamulin, Raspelo 12. stoljeća u Zadru, ZR 16.2/3, 1967, p. 169, 173.
} 
it appears highly likely that the destroyed crucifix from the Benedictine nunnery had originally only one verse inscription displayed under the arms of Christ, as is the case with other two crucifixes from Zadar (see further).

Due to the mediocre quality of the only two remaining photographs, and the fact that the crucifix no longer exists, scholars are constrained to operate with the transcription provided by $\mathrm{C}$. Cecchelli ${ }^{23}$. While editing the catalogue of the most significant works of art in Zadar, Cecchelli saw the crucifix de visu, a little less than a decade before it was destroyed. The inscription along the lower edge of the transverse arm of the cross reads:

\section{+SOL LATET ORBISQVE TREMIT SAXVM CREPITAT ISTE CEDIT}

(The sun is hidding, the world is trembling, the cliff is shaking, this one dies)

The reading of the upper inscription is somewhat more problematic. However, by reaching to the original text, out of which the verse was extracted (and presuming it was faithfully reproduced) it is possible to establish that the two double-rimed verses originated from the mid-1100s poem Carmen paraeneticum ad Rainaldum ${ }^{24}$. In the $17^{\text {th }}$-century the poem was included in the Opera omnia of Saint Bernard of Clairveaux. Since then his authorship was questioned, and the uncertain author is often referred to as Pseudo-Bernard. Two verses inscribed on the crucifix were:

\section{QVISQVIS AMAT CHRISTVM MVNDVM NON DILIGIT ISTVM / SED QVASI FETORES SPERNENS ILLIVS AMORES}

(Who loves Christ does not love this world / but scorns its love as it scorns a stench) ${ }^{25}$.

This lengthy poem was highly popular in the later middle Ages, and as such was circulating in the Adriatic area. Literary culture of the Eastern Adriatic is reasonably well studied, whereas the ways by which texts were circulating are usually impossible to trace ${ }^{26}$. B. Lučin has recently discovered that an epitaph walled in

\footnotetext{
${ }^{23}$ Catalogo delle cose d'arte e di antichità d'Italia: Zara, ed. C. Cecchelli, Roma 1932, p. 151 (caetera: C. Cecchelli, Catalogo).

${ }^{24}$ The full poem is available at the Biblioteca Catolica Omnia; Auctor Incertus, Carmen paraeneticum ad Rainaldum, 1100-1200; http://www.documentacatholicaomnia.eu/04z/z_1100-1200_ _Auctor_Incertus_Carmen_Paraeneticum_Ad_Rainaldum_MLT.pdf.html [15 IV 2016].

${ }^{25}$ Transcription presented by Cecchelli in Catalogo di cose d'arte slightly differs from the original text in the Pseudo-Bernard's poem. Translation according to G. Gamulin, The painted crucifixes..., p. 50 (n. 25).

${ }^{26}$ Cf.: N. Kolumbić, Hrvatska književnost na prijelazu iz romanike u gotiku, [in:] Majstor Radovan i njegovo doba, ed. I. BABIĆ, Trogir 1994, p. 241-246; J. BRATUlić, Hrvatska srednjovjekovna poezija latinskog jezičnog izraza, [in:] IDEM, Sjaj baštine. Rasprave i članci o hrvatskoj dopreporodnoj književnosti, Split 1990, p. 35-51.
} 
the cloister of the Franciscan friary in Split is composed of the verses from the same Pseudo-Bernard's work ${ }^{27}$. The six verses inscribed on the epitaph were extracted from the original poem and then set together forming a new one. The defunct, Leo Cacete, died in 1296, at the end of the same century in which the Benedictine crucifix from Zadar was fabricated. Future research on book culture in these cities will possibly bring to light new findings about the circulation and use of this particular poem.

The second example from Zadar is an impressive life-sized carved and polychrome image of the Living Christ, best known as the crucifix from the Collection of the Saint Francis' Friary. Generally dated around or shortly after 1200, this crucifix bares three registers of inscriptions. The first and the highest one, the titulus, is a combination of the chi-ro monogram and the shortened Latin reference to Jesus as the king of Jews, REX IVDEORVM. On the upper part of the arm the Greek word for Crucifixion, ICTAVBR $\Omega$ CIC, is inscribed ${ }^{28}$. On the lower part runs biblically inspired verse, possibly an elaboration of a section from Ezekiel $(39,17-18)$ :

\section{+IN ME CREDENTES AD ME CONCVRRITE GENTES}

(People who believe in me, run to me)

B. Brenk in 1999 labelled this inscription as "typically Franciscan". Without going deeper in his argument of the origin of inscription, he pointed to the fact that the crucifix was commissioned for a Franciscan church and its style and typology is Umbro-Tuscan, that is, as well tied to the artistic production of the Mendicant orders in central Italy ${ }^{29}$. However, the Franciscan church in Zadar was consecrated only in 1280, and, although Brenk suggests the dating of the crucifix to the end of the $13^{\text {th }}$-century, the generally accepted dating places its manufacturing much earlier.

Finally, the crucifix from the Saint Michael's church is roughly dated to the $13^{\text {th }}$-century, and exhibits similar formal characteristics as the Franciscan one. Likewise other two examples from Zadar its original provenance is not certain since no archival evidence acknowledge its original location and context. Generally accepted reading of its verse in scholarly publications is: REX OBIT HIC PLORAT MARIA DOLET IMPIVS ORAT ${ }^{30}$. Even though the inscription is generally well

\footnotetext{
${ }^{27}$ B. Lučin published his finding on blog "MARVLVS ET AL". See the entry "Još jedan splitski srednjovjekovni epitaf”: http://marcusmarulus.blogspot.com/2011/06/jthe os-jedan-splitski-srednjovjekovni.html [15 IV 2016].

${ }^{28}$ G. Gamulin, Raspelo iz 12. stoljeća..., p. 169.

${ }^{29}$ B. Brenk, Il ciborio esagonale di San Marco a Venezia, [in:] L'arte di Bisanzio e l'Italia al tempo dei Paleologi 1261-1453, ed. A. Iacobini, M. Della Valle, Roma 1999, p. 147-148.

${ }^{30}$ The transcription provided by Cecchelli was reproduced in all succeeding publications: C. CECChelli, Catalogo..., p. 151; G. Gamulin, The painted crucifixes..., p. 116; E. Hilje, Cat. No. 16..., p. 96. Cecchelli should also be credited for pointing to similar inscriptions. Another example, which
} 
preserved, some letters have lacerated, in particular the word read as MARIA. It is clear, however, that the word finishes with an AR, followed by an abbreviation for US, which makes the proposed reading of the word unlikely. When comparing this inscription with a relatively numerous group of depictions baring the similar verse, it is convincing to read the word as CARUS. The "beloved one" is identifiable with John the Evangelist, still visible on the Christ's left. As a consequence, the third word of inscription has to be read as HEC (fem.), referring to Mary, now obliterated but once depicted on the opposite end of the cross. The full text must be therefore transcribed as:

\section{+REX OBIT HEC PLORAT CARVS DOLET IMPIVS ORAT}

(The King dies, she cries, the beloved one grieves, the impious one prays) ${ }^{31}$

The verse, including its alternated versions, can be found in at least ten other examples, which makes the cited Rex obit inscription frequently used through the Latin West ${ }^{32}$. Probably more striking is the fact that the inscription was broadly disseminated, from Iberian Peninsula and Northern Europe to, as this case attest, the East Adriatic coast. Together with the considerable geographical diffusion of the verse, it can be found on different supports, as well as in various contexts. For example, the verse is inscribed on one of the pier reliefs in the monastery cloister (Santo Domingo de Silos in Spain), church portal (Ribe cathedral in Denmark), and prayer books once used through the Continent. The contexts also vary: the inscription on the church portal was addressing the wide audience, the cloister is a semi-public space, while devotional books had different, surely more private use $^{33}$. Addition of Zadar crucifix to this group both broadens the area in which the inscription was diffused and expands the variety of its contexts. Given the fact that a monumental crucifix was most obviously located in the sacral space, it makes it a unique case.

The inscription is an opening verse of a poem by Hildebert of Lavardin, or one of his followers. Hildebert's eight verses long poetry came down to us in the Copenhagen miscellanea and is therefore known as the Copenhagen octave $e^{34}$. It was used as a prayer or a hymn, and possibly even as a liturgical text ${ }^{35}$. The most recent contribution to the understanding of the Rex obit inscription is a remarkable

\footnotetext{
was known to him and which he confronted with the inscription on the Zadar crucifix, is the one found on the cover of the Trier Gospel from the $12^{\text {th }}$ century: Ista flet, hec surgit, obit hic, cadet hec, dolet iste.

${ }^{31}$ I am following the translation in: P. Sсотт BRown, The verse inscription from the deposition relief at Santo Domingo de Silos: word, image, and act in medieval art, JMS 1/1, 2009, p. 95.

${ }^{32}$ P. SCOTt BRown, op. cit., p. 88-89.

${ }^{33}$ Ibidem, p. 89, 100.

${ }^{34}$ For the whole poem cf.: ibidem, p. 95.

${ }^{35}$ Cf. R. Favreau, Sources es inscriptions médiévales, CRAIBL 153/4, 2009, p. 1295-1296.
} 
article by P. Scott Brown. In his thought-provoking discussion on the Deposition relief in Silos, Scott Brown has convincingly argued how the inscription served as a mnemonic device. Combined with the imagery, it functioned as a help in evocation of a larger text. For devotees who were familiar enough with this poem, the text and imagery were devices to "trigger devotional and performative responses to works of art" ${ }^{\prime 36}$. Textual and visual strategies - verse inscription and relief - created the devotional pattern so that the beholder was instructed to meditate upon the Passion of Christ using the exact poem and specific object of devotion.

The next aspect of inscription, as well pointed out by Scott Brown, is its flexibility. It could have served as a support to either Crucifixion or Deposition ${ }^{37}$. As a matter of fact, its presence in Zadar is even more captivating when confronted with the iconography of the crucifix. Besides the figure of Saint Michael in the highest part of the vertical limb of the cross, all other figures are indicated in the text. The Christ as the central figure is the king that dies (REX OBIT). Secondary figures, Mary, once depicted on Christ's right side is weeping (HEC PLORAT), while John the Evangelist, his teacher's beloved one, is mourning (CARVS DOLET). Holding their inclining heads with both hands, supplicants in grief are pointed out in the verse causing that both imagery and text displayed the right way to meditate over the death of Christ. Following their example, double-stressed by text and imagery, devotees were instructed on how to compassionate with the death of Christ.

Furthermore, the devotee is explicitly mentioned at the end of the verse inscription. The expression "the indigenous one prays" (IMPIVS ORAT) stands for the devotee before a crucifix. In this case this is more than a formula frequently used in medieval sources where patrons referred to themselves as indigenous or sinful; on Saint Michael's crucifix the impius had a precise function in devotional experience. As Scott Brown makes clear, the "indigenous one" in the verse was identified with the "indigenous" one in the real sphere before the crucifix through "conscious mimetic identification" 38 . Since none of the figures depicted can be interpreted as "impious," in the eyes of the devotee it becomes ego ${ }^{39}$.

\section{Text-Image-Text Strategies and the Pious Performance}

After briefly discussing the origin of inscriptions and their function and use, it is necessary to turn our attention to the interrelation between the text and imagery. In comparing the message communicated through verses with iconography of the crucified Christ, strictly semantically speaking, it is clear that it was not obligatory

\footnotetext{
${ }^{36}$ P. Scott Brown, The Verse Inscription..., p. 91.

${ }^{37}$ Ibidem, p. 89.

${ }^{38}$ Ibidem, p. 97.

${ }^{39}$ Ibidem, p. 97.
} 
for the text and imagery to complement one another. For instance, Christ on the destroyed Benedictine cross from Zadar was a Living one. The depiction of Christ in his triumph over death is in opposition to the apocalyptically intoned text. While the imagery suggests Christ's victory, the verse stresses antipodal message - the hiding sun, trembling world, and the shaking of the cliff - all followed by the death on the cross. The use of pronoun "this one" (ISTE) deliberately establishes connection with the imagery. The inscription is referring to Christ, but while depicted as living on the cross He died (CEDIT) in inscription.

The question of victory over death, expressed either in text or imagery, is of particular importance for the topic under discussion. On the mid-1 $3^{\text {th }}$-century crucifix in San Pietro in Vinculis in Pisa, better known as San Pierino, Christ has died on the cross and Mary and John are morning over his death ${ }^{40}$. Nonetheless, the verse above Christ's arms does not describe death of Christ nor does it point to supplicants in pain. On the contrary, the Christ is referred to as a "destructor of death, restorer and creator of life." The inscription in original reads:

\section{+MORTIS DESTRVCTOR VITE REPARATOR ET AVCTOR}

Observing from this angle, it is interesting to point out that the image of the suffering Christ was accompanied by a VICTOR MORTIS caption on the two crucifixes from Sicily, both dated to the $13^{\text {th }}$ century $y^{41}$. Cited cases attest that text and imagery were sometimes contrasting. The medieval devotee would have found himself before the object consisting of text and imagery, semantically conflicting between them.

Bearing in mind the use of crucifixes with inscriptions as devotional objects, one might ask were medieval viewers perceiving this text-image inconsistency, as we do today? According to M. Bacci the answer is negative. From our modern-day art-historical perspective the iconographical schemes of Living and Suffering Christ do seem too different not to be perceived. However, inscriptions on crucifixes indicate how during the $13^{\text {th }}$ century, when the Suffering Christ had become a prevalent iconographical theme, the understanding of Passion did not necessary change ${ }^{42}$. Two crucifixes from Pisa and Zadar speak in favor of these observations

\footnotetext{
${ }^{40}$ For the San Pierino crucifix cf.: L. CARletti, Croce dipinta (no. 41), [in:] Cimabue a Pisa. La pittura pisana del Duecento da Giunta a Giotto, ed. M. Burresi, A. Caleca, Ospedaletto 2005, p. 178-179. ${ }^{41}$ M.C. Di Natale, Le croci dipinte in Sicilia: l'area occidentale dal XIV al XVI secolo, Palermo 1992, p. $7,13$.

${ }^{42}$ In other words, the change of iconography was not followed by the shift in the perception of Christ's nature. In the same way, two crucifixes from Arezzo (the end of the $12^{\text {th }}$ and the first half of the $13^{\text {th }}$ century) on the perisome display designation of Christ from the Gospel of John $(17,14)$ : REX REGUM ET DOMINUS DOMINANTIUM. M. BACCI, 'Pro remedio animae.' Immagini sacre e pratiche devozionali in Italia centrale (secoli XIII e XIV), Pisa 2000, p. 108-109, 111.
} 
and support the general remark in dealing with inscriptions, which, as scrutinized by $\mathrm{K}$. Ambrose, do not consistently ground the meaning of a work of art but can stand in any number of semantic relations to $i t^{43}$. Furthermore, all this calls to mind a D. Freedberg's stance on crucifixes as fetishistic object to a much greater extent than all other images ${ }^{44}$. According to Freedberg, it may be argued that, since they were the most impassioned focus of beholders, their form (and iconography) were more or less irrelevant to the kinds of response they engendered ${ }^{45}$.

However, the problem as I see it, becomes complicated when we are dealing with devotional objects in question, and can broadly be summarized in one question: Was it text or image that played a decisive role in development of devotional practices? Or, to put it differently, was Passion communicated by text, imagery, or a combination of both? Although it is tempting to answer "both", the two cited crucifixes and the ambiguity that exists in their verses require a more elaborate response. At this point it is necessary to turn our attention to the aspects of devotional performance. Consequently, rather than focus only on the visionary, it is mandatory to include into the discussion other senses as well.

The growing scholarship on the role of senses in devotion paints it as a deeply multisensory experience. Vision, although perceived either as a reliable or blurred mode of perception ${ }^{46}$, was irreplaceable since it was crucial to have a focus of worship. The visual representation was therefore required. When looking at the image as a whole, the devotees would concentrate on eyes and head. Eyes, notes M. Holmes, emerge as critical element in representational econom $y^{47}$. This is, in fact, particularly true for the iconography of the Living Christ whose wide-open eyes are the most distinct part of the face. The importance of the psychology of eyes and physiognomy in general is evident in the case of the destroyed Benedictine cross whose leaned aureole was pointing the eyes of the Crucified directly to the ones of the devotee ${ }^{48}$.

Medieval piety was also somatic. The touch provided immediate knowledge of the world, and, when controlled, was able to lead to God ${ }^{49}$. J. Cannon has recently dedicated a study to the visual representations of touching and kissing of the Virgin's foot

\footnotetext{
${ }^{43} \mathrm{~K}$. Ambrose, Attunement to the Damned of the Conques Tympanum, Ges 50/1, 2011, p. 12-13.

${ }^{44}$ D. Freedberg, The Power of Images: Studies in the History and Theory of Response, Chicago-London 1991, p. 307.

${ }^{45}$ Ibidem.

${ }^{46}$ For the different perceptions of the senses in the Middle Ages cf.: J.E. Jung, The Tactile and the Visionary: Notes on the Place of Sculpture in the Medieval Religious Imagination, [in:] Looking Beyond: Visions, Dreams, and Insights in Medieval Art and History, ed. C. Hourihane, Princeton 2010, p. 203-204, 207-210.

${ }^{47}$ M. Holmes, The Miraculous Image in Renaissance Florence, New Haven 2013, p. 183.

${ }^{48}$ For the reciprocity in rituals of gazing cf.: T. Lentes, 'As Far as the Eye Can See...': Rituals of Gazing in the Late Middle Ages, [in:] The Mind's Eye: Art and Theological Argument in the Middle Ages, ed. J.F. Hamburger, A. Bouché, Princeton 2005, p. 360-362.

${ }^{49}$ J.E. Jung, The Tactile and the Visionary..., p. 208.
} 
in early Sienese panel painting. A wide range of evidence she presented speak in favor of this kind of interaction with large-sized images as a usual practice in central Italy ${ }^{50}$, typical for devotional practices of both East and West ${ }^{51}$. The same act was applied in lay domestic spaces where small-scale panels, usually triptychs, triggered the same form of tactile devotion ${ }^{52}$. The damage caused by such a use of objects is rarely preserved, and evidence on their haptic handling can usually be found only in literary accounts ${ }^{53}$. However, this is not the case with crucifixes displaying a verse inscriptions.

There are two basic types of physical engagement with devotional objects. The first one is direct contact with palms. The second one is more complex because consists of a gift-offering to an image as a sign of a vow in form of a silver or gold plaque, candle, wax body part or even the whole figure ${ }^{54}$. The plaques fall under this category because were attached onto the object through physical contact. Devotees were pinning ex voto gifts on the Venetian crucifix from Santa Maria dei Frari and the Benedictine crucifix from Zadar. On the other hand, the relief from Santo Domingo de Silos and, as I will suggest below, other crucifixes from Zadar are worn out due to the constant touching of the feet of Christ by devotees. In other words, while eyes were instrumental for the sense of sight, the focus of the sense of touch were feet ${ }^{55}$.

Seeing, as it seems, was initial step in inspiring veneration, and praying to Christ was much easily performed with an image of Christ before one's eyes. Distinction between these two modes of perception is a modern one, since it was rather fluid in the Middle Ages ${ }^{56}$. Therefore, rather than defining touch as a secondary mode of perception, meaning that it came after the visionary, in the case of crucifixes with inscriptions it seems reasonable to opt for the contemporaneity

${ }^{50}$ J. CAnnon, Kissing the Virgin's Foot: Adoratio Before the Madonna and Child enacted, depicted, imagined, SIc 31, 2010, p. 19-23.

${ }^{51}$ S. Brajović - J. ERdeljan, Praying with senses. Examples of icon devotion and the sensory experience in medieval and early modern Balkans, 3ОГ 39, 2015, p. 57-63.

52 D.G. Wilkins, Opening the Doors to Devotion: Trecento Triptychs and Suggestions Concerning Images and Domestic Practice in Florence, [in:] Italian Panel Painting of the Duecento and Trecento, ed. V.M. SснміDт, Washington 2001, p. 376.

${ }^{53}$ G. Lutz, The Drop of Blood: Image and Piety in the Twelfth and Thirteenth Century, Preter 4/1, 2015, p. 37-51.

${ }^{54}$ Cf. M. Holmes, Ex-votos: Materiality, Memory, and Cult, [in:] The Idol in the Age of Art. Objects, Devotions and the Early Modern World, ed. M.W. Cole, R. Zorach, Farnhout 2009, p. 159-181.

${ }^{55}$ The legs must have played particular role in the devotion of the $13^{\text {th }}$ century, primarily because of Saint Francis. On monumental crucifixes he was represented as adoring the wounds on the feet of Christ (see, for instance, $13^{\text {th }}$-century Umbrian crosses). Even later Franciscan sources, such as writings of St Bernardine of Siena, underline Francis' devotion to the legs of the Crucified. M. Bоsкovits, Immagine e preghiera nel tardo Medioevo: osservazioni preliminari, ArtC 76, 1988, p. 94.

${ }^{56}$ C. Lawless, Sensing the Image: Gender, Piety and Images in Late Medieval Tuscany, OAJ 4, 2014-2015, p. 63. 
of both perceptions. Indeed, it is not difficult to imagine devotees fixing their eyes on the face of Christ, clinging onto His feet, and addressing Him with prayers by reading and pronouncing the words displayed on the cross.

Here, finally, the verse inscription, prayer or most likely used as one, offered a devotional pattern to devotees ${ }^{57}$. Aside from containing the rendering of Christ as the King of the Glory, Author of life or Victor over death, its textual strategies added a further aspect to the devotional performance. The use of the present tense provided a direct link between the historical time of Christ's death on the cross and the moment when the devotee was meditating under the crucifix ${ }^{58}$. This is a clear indication on how the presence of devotee in the verse also functioned to transcend the object, stating that the Passion is occurring here and now ${ }^{59}$. In such a way the relation of the historical event on the Golgotha with the time, space, and experience of the devotee was created by bridging several realities. The present tense is used on the Benedictine crucifix as well, the difference being that the verse indicates just one of the depicted figures, which is the dying Christ. Other motifs in inscription (hiding sun, trembling world and the shaking cliff) aim to (re)create the moment of Christ's death in the mind of the devotee. Since none of the motifs were depicted, devotees were imagining them in the process of meditation before the crucifix.

The Frari crucifix from Venice and Franciscan from Zadar have somewhat different verses. On the Venetian one the verse is referring directly to the devotee pointing out to him (HE has shown his love to YOU). The first verse directly addresses the one praying before the crucifix, while the second one is more general, aiming to underscore Christ's love for the world that caused his passion and crucifixion. On the crucifix from Zadar words inscribed are in fact words by Christ himself, written in the first person. The spread arms of Living Christ are combined with the powerful plea for running towards Saviour on the cross. For imperative form of its verse (concurrite) the Franciscan crucifix can be interpreted as a speaking work of art whose 'voice' directs viewers to adopt a pious and emotional respons $e^{60}$. Textual strategies of communicating the Passion, as all these examples illustrate, were at least two: enacted or by explicitly mentioning the one praying before the cross, or by using the present tense. Intensifying the potency of devotional experience and reaching out to the devotee was of particular importance, and thus the purpose they served was profoundly practical. Discrepancy

\footnotetext{
${ }^{57}$ Epigrams and inscriptions in the Byzantine world were also used in similar way, cf.: B.V. Pentcheva, Epigrams on Icons, [in:] Art and Text in Byzantine Culture, ed. L. JAMEs, Cambridge 2007, p. 120-122. ${ }^{58}$ P. Sсотt Brown, The Verse Inscription..., p. 96.

${ }^{59}$ The same can be deduced from the $9^{\text {th }}$-century meditation composed by Hrabanus Maurus: "concentrate upon the image (...) as if Christ were right now dying on the cross." H.L. Kessler, The French connection..., p. 138-139.

${ }^{60}$ L. Ross, Language in the Visual Arts: The Interplay of Text and Imagery, Jefferson 2014, p. 37.
} 
between imagery and text points to conclusion that inscriptions were conditioned by requirements of audience rather than that of iconography. It was their devotional effectiveness and contemplative potential that mattered.

\section{The Visibility of Verses and the Original Setting of Crucifixes}

Although evidence on the original location of crucifixes with inscriptions is scarce, the use of written text inscribed on them, as well as the strategies implemented in them, can yield further indication in aiming to solve this issue. Instrumental in understanding their function, it is a first step towards setting them before the eyes of medieval devotees ${ }^{61}$. None of the crucifixes here discussed has maintained its original position and neither written sources can easily solve the problem. Since the manufacturing of crucifixes in some cases predates written evidence even for centuries, they are usually of little use. When discussing the possible location of the Frari crucifix in the $13^{\text {th }}$-century church of Santa Maria Gloriosa, A. Augusti argued how monumental crucifixes were commonly placed in the triumphal arches or mounted above choir screens of Mendicant churches throughout the Apennine peninsula ${ }^{62}$. Her observation is most certainly correct, although the inscriptions running on the transverse limb of the crucifixes may point to different location for several reasons.

Firstly, all inscriptions on crucifixes are double-rimmed ones. Their metrification implies that medieval devotees, at least the ones capable of deciphering the text, pronounced them out loud. As argued above, the rimmed, short verse aimed to help the devotee not only to pronounce it, but also to memorise it, or even, as aptly argued by Scott Brown, to evoke the verses following the one inscribed. To enact the devotional performance of reading the verse, and contemplating on its meaning and imagery, it was obligatory for the object to be located near the beholder. In this regard, the placement of crucifixes in the triumphal arches does not seem convincing. How such placement does or does not apply to their function can be examined in the case of the Rex obit crucifix. After the modern restoration it was placed in the triumphal arch of the Saint Michael church in Zadar. The line of reasoning for such a placement was based on the general belief that monumental crucifixes were necessary hung in the triumphal arch, above the main altar. The same setting was proposed for the other two crucifixes from Zadar ${ }^{63}$. But does this allocation permit to read the inscription easily, if at all?

\footnotetext{
${ }^{61}$ For the setting of crucifixes within the interior of later-medieval churches cf.: V.M. SCHMIDT, Tavole dipinte. Tipologie, destinazioni e funzioni, [in:] L'arte medievale nel contesto 300-1300. Funzioni, iconografia, techniche, ed. P. PIVA, Milano 2006, p. 208-210.

${ }^{62}$ A. Augusti, Basilica dei Frari: arte e devozione, Venezia 1994, p. 20.

${ }^{63}$ I. Petricioli, Umjetnička baština samostana Sv. Marije u Zadru, [in:] Kulturna baština samostana Svete Marije u Zadru, ed. G. NovaK, V. MašTrović, Zadar 1968, p. 86; E. HiLje, Slikarstvo zadarske nadbiskupije od IV. do kraja XV. stoljeća, [in:] E. HiLJE - R. ToмIć, Slikarstvo..., p. 15.
} 
Material evidence may offer substantial evidence in reassessing the original setting. Prior to the bombing of Zadar, when Cecchelli detected the crucifix hanging besides the main entrance of the nunnery, he noted that the legs of Christ were abraded due to the "kisses of the devotees," with a small ex voto plaque attached ${ }^{64}$. During the restoration of the Frari crucifix in 1992 similar material evidence was found, with traces of numerous votive offerings once clustered in the bottom of Christ's legs ${ }^{65}$. When observing closely the feet of Christ on other crucifixes in Zadar, it is noticeable that the painted layer have deteriorated. In every single case the legs of Christ are destroyed due to the "pious vandalism," as this activity is amusingly defined ${ }^{66}$. These signs granted a special aura to the object that displayed it. More than just a visible proof of a worshiper's closeness to a particular object, these gradually visible signs of numerous palms, finger and lips imprinted a memory, created through the use of an object in devotion ${ }^{67}$.

However, the pious vandalism is a process, first signs of which are visible after years, if not decades. It may be objected, therefore, that the acts that caused damages and objects are not contemporary. It is true that some of these findings could easily be tied to the $15^{\text {th }}$ and $16^{\text {th }}$ centuries when the devotion to the Frari crucifix was at peak due to its activation as a miracles-working object ${ }^{68}$. But contrary to the Venetian case, crucifixes from Zadar were not wonder-working. It should be added that they are not listed in any of the Early Modern inventories of churches in Zadar which suggests that no cult or particular devotion was developed around them. C.F. Bianchi, author of the extensive $19^{\text {th }}$-century ecclesiastical history of Zadar, writes how the Saint Michael crucifix was possessed by confraternities from the $16^{\text {th }}$ century onwards ${ }^{69}$. Whether this was the confraternity of Lady of Snow or Lady of Varoš is not clear, and he is relaying on local narratives more than on written. The precise time of occurrence of damages is, indeed, uncertain. However, it seems reasonable to suppose that the non-existence of a later cult in the case of Zadar crucifixes can point to the conclusion that the process initiated right after their placement in sacred spaces. That was also the time when the religious literature displayed on crucifixes was circulating and eliciting response from devoted individuals.

Where, then, were these crucifixes placed within the church interiors? The evidence brought together so far - prominently placed, rimmed verse inscriptions, detailed iconography, as well as material evidence of devotional ware - point to the conclusion that the original location appears to have been accessible to church-

${ }^{64}$ C. Cecchelli, Catalogo..., p. 72.

${ }^{65}$ A. Augusti, Un crocifisso..., p. 155.

${ }^{66}$ E. Mognetti, Marks of Devotion: Case Study of a Crucifix by Lorenzo di Bicci, [in:] Italian Panel Painting..., p. 355.

${ }^{67}$ A.W.B. Randolph, Touching Objects. Intimate Experiences of Italian Fifteenth-Century Art, New Haven-London 2014, p. 228.

${ }^{68}$ C. Corsato, op. cit., p. 106.

${ }^{69}$ Cited in G. Gamulin, The painted crucifixes..., p. 116. 
goers, granting the physical proximity between beholders and these life-size paintings. Their most likely location are side altars, plausibly the ones dedicated to the Holy Cross. They commonly served as lay altars were the mass for the dead was delivered, and were traditionally erected in the middle of the nave, with their back attached to the choir screens or set against the lateral wall ${ }^{70}$. Frari crucifix was painted from both sides and, as students of this crucifix unanimously argue, textual and material evidence point to its setting "in the middle of the church" (a mezza chiesa) ${ }^{71}$.

Other altars could have displayed monumental crucifixes as well. For example, $13^{\text {th }}$-century Tuscan painter Coppo di Marcovaldo produced two crucifixes for the cathedral of San Zeno in Pistoia, one of which was intended for the choir screen, and the other for the altar of Saint Michael. The surviving cross (ca. 1274), today exhibited in cathedral, is usually identified with the one commissioned for the altar ${ }^{72}$. According to C. Frosinini, crosses displaying narrative scenes were not originally intended for altars and have not played any role in the liturgy. Taking into consideration detailed scenes on crosses, Frosinini draws connection between this group of crucifixes and lay piety rather than with liturgy ${ }^{73}$. It should be made clear, however, that our knowledge of the liturgical use of the side altars is poor. Apart from particular feast day, no daily celebrations seem to have taken place on these altars, and it is attainable that they have primarily served as "stages for devotion"74. Accordingly, the altar dedicated to Saint Michael in San Zeno cathedral would have been liturgically "active" only in occasion of the saint's feast day. However, the focus of much greater devotional interest was Coppo's crucifix ${ }^{75}$.

The further aspect of the liturgy versus devotion issue is the difficulty of defining the palpable linkage between works of art and strictly liturgical practices ${ }^{76}$. An exception to this general rule could be the Pisan crucifix whose Easter prefatio

\footnotetext{
${ }^{70}$ Much more attention has been dedicated to the Holy Cross altars in the Early Middle Ages. For symbolical, liturgical, and Eucharistic connotations cf.: A.E. Fisher, Cross Altar and Crucifix in Ottonian Cologne. Past Narrative, Present Ritual, Future Resurrection, [in:] Decorating the Lord's Table. On the Dynamics between Image and Altar in the Middle Ages, ed. S. KAspersen, E. Thunø, Copenhagen 2006, p. 43-62; K. IMEsch, The Altar of the Holy Cross and the ideal of Adam's progeny: 'Ut paradysiace loca possideat regionis', [in:] Death and Dying in the Middle Ages, ed. E.E. DuBruck, B.I. Gusick, New York 1999, p. 73-76.

${ }^{71}$ C. Corsato, op. cit., 103; A. Augusti, Un crocifisso..., p. 155. The figure painted on the retro of the cross is identified as Saint Mark; C. SANTINI, op. cit., p. 195 (n. 8).

${ }^{72}$ M. Boskovits (ass. by A. Labriola, A. TARTUfFi), The origins of Florentine painting, 1100-1270: A critical and historical corpus of Florentine Painting, vol. I, Florence 1993, p. 596.

${ }^{73}$ C. Frosinini, La riforma gregoriana e la nascita della croce dipinta, [in:] Pinxit Guillielmus. Il restauro della croce di Sarzana, ed. M. Ciatti, C. Frosinini, R. Bellucci, Firenze 2001, p. 27.

${ }^{74}$ J.E.A. Kroesen, The Altar and its Decorations in Medieval Churches. A Functionalist Approach, Med 17, 2014, p. 173 (n. 60).

${ }^{75}$ The document also stipulated a figura seu sepultura sancti Michaelis. For the original document and its translation in Italian cf.: M. Burresi - A. CAlecA, Le croci dipinte, Pisa 1993, p. 95.

${ }^{76}$ For a broader view see B. Williamson, op. cit.
} 
formula, as suggested by S. Sindig Larsen, could indicate the connection with Eucharistic celebration ${ }^{77}$. Moreover, the verse it displays is rather neutral in a sense that does not exhibit any of devotional strategies used on other crucifixes. Modern restoration undertaken in 2005 has revealed that the cross contained relics treasured in its lower part and that the mid- $13^{\text {th }}$-century crucifix incorporated an earlier one, which has led scholars to speculate on the high cultic value of the older crucifix $^{78}$. All these characteristics separate the Pisan crucifix from the other discussed here. The proposed location on the rood screen remains plausible ${ }^{79}$, even if, on the basis of the high devotional value of both object and relics, it can be argued that this crucifix was placed somewhere closer to the devotees.

A more concrete bonding of crucifixes with specific time in the liturgical year was suggested by Kessler. An iron ring on the back surface of the Rosano cross led him to hypothesize on its movability, namely during the Easter adoratio, despositio, and elevatio rituals ${ }^{80}$. The crucifixes have certainly played an important role in the Holy Week rituals as can be deduced from written sources, and the prefatio formula on the Pisan crucifix is no exception. Devotional and liturgical role of monumental crucifixes does seems self-evident, but there is usually little or no firm ground to tide specific crucifix with surviving descriptions of Easter practices. Moreover, by the late $12^{\text {th }}$-century large Deposition scenes and, from the middle of the next century, crucifixes with movable arms emerged on the devotional landscape of medieval Europe ${ }^{81}$. These objects could have suited much better the requirements of the Holy Week practices then large and heavy crucifixes whose size and function point to their stationarity rather than movability.

\section{With and without Verse Inscription. Conclusion}

Nevertheless, the direct, close, and quotidian engagement with the image, as Holmes puts $\mathrm{it}^{82}$, led to both emotional and contemplative responses, as well as to the performance of several devotional acts and ritual practices. Far from being passive observers, devotees would meditate on the Passion of Christ by looking at the

\footnotetext{
${ }^{77}$ The full verse is as follows: "Qui mortem nostram moriendo destruxit, et vitam resurgendo reparavit". Cited in M. BACCI, 'Pro remedio animae'..., p. 109, 455.

${ }^{78}$ M. BACCI, Shaping the Sacred: Painted Crosses and Shrines in Thirteenth-Century Pisa, RJBH 38, 2007-2008, p. 122, 127.

${ }^{79}$ Bacci writes how the crucifix possibly hanged from a now disappeared rood screen, M. BAccI, Shaping the Sacred..., p. 122.

${ }^{80}$ H.L. Kessler, Inscriptions..., p. 178-180.

${ }^{81}$ Cf. K. Kopania, Animated Sculptures of the Crucified Christ in the Religious Culture of the Latin Middle Ages, Warsaw 2010.

${ }^{82}$ M. Holmes, The Miraculous Image..., p. 209. Although Holmes in her study refers primarily to the miracle- and wonder-working images, the quoted section holds true for images without a particular cult.
} 
Crucified, gazing at His eyes, wounds and mourning supplicants, doing the same by reading out loud the verse inscription, reaching out for Christ's feet, attaching votive gifts and lighting candles - all of which constituted vital parts of the multisensory and physically engaging devotion in the Middle Ages ${ }^{83}$. The most important aspect added by inscriptions to their function and use is directing the spectator in his/her devotion by offering a specified prayer, as well as through its reciting and, finally, hearing the inscribed message.

At first sight nothing seems to distinguish crucifixes with inscriptions from other crucifixes: their iconography is equal and their size and materiality inserts in the variety of the late medieval monumental sculpture and painting. On the other hand, art historians include them in the well-known general scheme of crucifixes hanging from the vaults of the church, applied in scholarship to all extant examples. A closer examination of not numerous, but intriguing group of crucifixes with prayer-inducing verses, as I hope to have demonstrated, shows how they required a multifaceted response and were profoundly experienced by their audience. More generally speaking, they underline the important fact that not all typologically equal objects (devotional or not) triggered the same kind of response. For instance, in her discussion on the various functions of the vita panels, J. Cannon has argued how panels of women saints from central Italy did not necessary have correspondent type and function ${ }^{84}$. All equal in appearance, they could have served for different religious and devotional purposes. Crucifixes here discussed represent the comparable, if not the equivalent functional diversity within the same typological framework. To repeat Cannon's concluding remarks, similarity of type should not lead us to assume similarity of function ${ }^{85}$.

\section{Bibliography}

\section{Secondary literature}

Aмвrose K., Visual poetics of the Cluny hemicycle capital inscriptions, W\&I 20/2, 2004, p. 155-164. Ambrose K., Attunement to the Damned of the Conques Tympanum, Ges 50/1, 2011, p. 1-17.

Augusti A., Un crocifisso duecentesco ai Frari, VenA 7, 1993, p. 153-156.

Augusti A., Basilica dei Frari: arte e devozione, Venezia 1994.

\footnotetext{
${ }^{83}$ For the most recent comprehensive contribution to the field cf.: B. CASEaU, The Senses in Religion: Liturgy, Devotion, and Deprivation, [in:] A Cultural History of the Senses in the Middle Ages, ed. R.G. Newhauser, London 2014, p. 89-110. For devotion to crucifixes cf.: S. Lipton, "The Sweet Lean of His Head": Writing about Looking at the Crucifix in the High Middle Ages, S 80/4, 2005 p. 1172-1208.

${ }^{84}$ J. Cannon, Beyond the Limitations of Visual Typology: Reconsidering the Function and Audience of Three Vita Panels of Women Saints c. 1300, [in:] Italian Panel Painting..., p. 290-311.

${ }^{85}$ Ibidem, p. 307.
} 
BACci M., Shaping the Sacred: Painted Crosses and Shrines in Thirteenth-Century Pisa, RJBH 38, 2007-2008, p. 113-129.

BACCI M., 'Pro remedio animae'. Immagini sacre e pratiche devozionali in Italia centrale (secoli XIII e XIV), Pisa 2000.

BABIĆ I., Unutarnja strana lunete glavnog portala trogirske katedrale - djelo majstora Radovana, ShP III/21, 1991, p. 205-244.

Boskovits M. (ass. by A. Labriola, A. Tartuffi), The origins of Florentine painting, 1100-1270: A critical and historical corpus of Florentine Painting, vol. I, Florence 1993.

Bosкoviтs M., Immagine e preghiera nel tardo Medioevo: osservazioni preliminari, ArtC 76, 1988, p. 93-104.

Brajović S. - J. ERdeljan, Praying with senses. Examples of icon devotion and the sensory experience in medieval and early modern Balkans, Зог 39, 2015, p. 57-63.

Bratulić J., Hrvatska srednjovjekovna poezija latinskog jezičnog izraza, [in:] IDEM, Sjaj baštine. Rasprave i članci o hrvatskoj dopreporodnoj književnosti, Split 1990, p. 35-51.

Brenk B., Il ciborio esagonale di San Marco a Venezia, [in:] L'arte di Bisanzio e l'Italia al tempo dei Paleologi 1261-1453, ed. A. Iacobini, M. Della Valle, Roma 1999, p. 143-157.

Burresi M. - A. Caleca, Le croci dipinte, Pisa 1993.

Cannon J., Kissing the Virgin's Foot: Adoratio before the Madonna and Child enacted, depicted, imagined, SI 31, 2010, p. 1-50.

Cannon J., Beyond the Limitations of Visual Typology: Reconsidering the Function and Audience of Three Vita Panels of Women Saints c. 1300, [in:] Italian Panel Painting of the Duecento and Trecento, ed. V.M. Schмidt, Washington 2001, p. 291-314.

Carletti L., Croce dipinta (no. 41), [in:] Cimabue a Pisa. La pittura pisana del Duecento da Giunta a Giotto, ed. M. Burresi, A. CAlecA, Ospedaletto 2005, p. 178-179.

Caseau B., The Senses in Religion: Liturgy, Devotion, and Deprivation, [in:] A Cultural History of the Senses in the Middle Ages, ed. R.G. Newhauser, London 2014, p. 89-110.

Cecchelli C. (ed.), Catalogo delle cose d'arte e di antichità d'Italia: Zara, Roma 1932.

Consato C., Public Piety and Private Devotion: The Altar of the Cross, Titian and the Scuola della Passione at the Frari, [in:] Santa Maria Gloriosa dei Frari: Immagini di Devozione, Spazi della Fede / Devotional Spaces, Images of Piety, ed. C. Corsato, D. Howard, Padova 2015, p. 101-116.

Favreau R., Sources des inscriptions médiévales, CRAIBL 153/4, 2009, p. 1277-1330.

Favreau R., Fonctions des inscriptions au moyen âge, CCM 32, 1989, p. 203-232.

Fisković I., Crucifixion with the Living Christ, $12^{\text {th }} / 13^{\text {th }}$ c., [in:] The Croats: Christianity, Culture, Art: Exhibition Catalogue, Musei Vaticani 1990-2000, Zagreb 1999, p. 264-265.

Fisković I., Romaničko slikarstvo u Hrvatskoj, Zagreb 1987.

Fisher A.E., Cross Altar and Crucifix in Ottonian Cologne. Past Narrative, Present Ritual, Future Resurrection, [in:] Decorating the Lord's Table. On the Dynamics between Image and Altar in the Middle Ages, ed. S. Kaspersen, E. Thunø, Copenhagen 2006, p. 43-62.

Freedberg D., The Power of Images: Studies in the History and Theory of Response, Chicago-London 1991.

Frosinini C., La riforma gregoriana e la nascita della croce dipinta, [in:] Pinxit Guillielmus. Il restauro della croce di Sarzana, ed. M. Ciatti, C. Frosinini, R. Bellucci, Firenze 2001, p. 27-30.

Gamulin G., The Painted Crucifixes in Croatia, trans. E. Elias Bursać, Zagreb 1983. 
Gamulin G., Raspelo iz 12. stoljeća u Zadru, ZR 16/2-3, 1967, p. 167-176.

Garrison E.B., Italian Romanesque Panel Painting. An Illustrated Index, Florence 1949.

Gramigni T., Le iscrizioni della croce di Sarzana e le scritture d'apparato toscane del XII secolo, [in:] Scrittura epigrafica e scrittura libraria: fra Occidente e Oriente, ed. M. Maniaci, P. Orsini, Cassino 2015, p. 133-174.

Hilje E. - R. Tomić, Slikarstvo: umjetnička baština Zadarske nadbiskupije, Zadar 2006.

HiljE E., Slikarstvo zadarske nadbiskupije od IV. do kraja XV. stoljeća, [in:] E. HiljE, R. Toмić, Slikarstvo: umjetnička baština Zadarske nadbiskupije, Zadar 2006, p. 5-36.

Holmes M., The Miraculous Image in Renaissance Florence, New Haven 2013.

Holmes M., Ex-votos: Materiality, Memory, and Cult, [in:] The Idol in the Age of Art. Objects, Devotions and the Early Modern World, ed. M.W. Cole, R. Zorach, Farnhout 2009, p. 159-181.

IMEsch K., The Altar of the Holy Cross and the ideal of Adam's progeny: 'Ut paradysiace loca possideat regionis', [in:] Death and Dying in the Middle Ages, ed. E.E. DuBruck, B.I. Gusick, New York 1999, p. 73-106.

Jung J.E., The Tactile and the Visionary: Notes on the Place of Sculpture in the Medieval Religious Imagination, [in:] Looking Beyond: Visions, Dreams, and Insights in Medieval Art and History, ed. C. Hourihane, Princeton 2010, p. 203-240.

Kendall C.B., The Allegory of the Church: Romanesque Portals and Their Verse Inscriptions, Toronto 1998.

Kendall C.B., The Gate of Heaven and the Fountain of Life: Speech-Act Theory and Portal Inscriptions, EMS 10, 1993, p. 111-125.

Kessler H.L., The French connection: word and image on the Rosano cross, [in:] La pittura su tavola del secolo XII. Riconsiderazioni e nuove acquisizioni a seguito del restauro della Croce di Rossano, ed. C. Frosinini, G. Wolf, A. Monciatti, Firenze 2012, p. 133-140.

Kessler H.L., Inscriptions on Painted Crosses and the Spaces of Personal and Communal Meditation, [in:] Inscriptions in Liturgical Spaces [= AAAHP 24], ed. K.B. Aavitsland, T. Karlsen Seim, Rome 2011, p. 161-184.

Klaić N., Petricioli I., Zadar u srednjem vijeku do 1409. godine, Zadar 1976.

Kolumbić N., Hrvatska književnost na prijelazu iz romanike u gotiku, [in:] Majstor Radovan i njegovo doba, ed. I. BABIć, Trogir 1994, p. 241-246.

Kopania K., Animated Sculptures of the Crucified Christ in the Religious Culture of the Latin Middle Ages, Warsaw 2010.

Kroesen J.E.A., The Altar and its Decorations in Medieval Churches. A Functionalist Approach, Med 17, 2014, p. 153-183.

LAWLESS C., Sensing the image: gender, piety and images in late medieval Tuscany, OAJ 4, 2014-2015, p. 61-74.

Lentes T., 'As Far as the Eye Can See...': Rituals of Gazing in the Late Middle Ages, [in:] The Mind's Eye: Art and Theological Argument in the Middle Ages, ed. J.F. Hamburger, A. Bouché, Princeton 2005, p. 360-373.

Lipton S., "The Sweet Lean of His Head": Writing about Looking at the Crucifix in the High Middle Ages, S 80/4, 2005, p. 1172-1208.

Lutz G., The Drop of Blood: Image and Piety in the Twelfth and Thirteenth Century, Preter 4/1, 2015, p. 37-51. 
Mognetti E., Marks of Devotion: Case Study of a Crucifix by Lorenzo di Bicci, [in:] Italian Panel Painting of the Duecento and Trecento, ed. V.M. Schмid, Washington 2001, p. 355-369.

Mostert M., Reading Images and Text: Some Preliminary Observations Instead of An Introduction, [in:] Reading Images and Texts. Medieval Images and Texts as Forms of Communication: Papers from the Third Utrecht Symposium on Medieval Literacy, Utrecht, 7 - 9 December 2000, ed. M. HAGEman, M. Mostert, Turnhout 2005, p. 1-7.

Di Natale M.C., Le croci dipinte in Sicilia: l'area occidentale dal XIV al XVI secolo, Palermo 1992.

Papalexandrou A., Text in Context: Eloquent Monuments and the Byzantine Beholder, W\&I 17/3, 2001, p. 259-283.

Pentcheva B.V., Epigrams on Icons, [in:] Art and Text in Byzantine Culture, ed. L. James, Cambridge 2007, p. $120-138$.

Petricioli I., Umjetnička baština samostana Sv. Marije u Zadru, [in:] Kulturna baština samostana Svete Marije u Zadru, ed. G. NovaK, V. MAštrović, Zadar 1968, p. 61-100.

Randolph A.W.B., Touching Objects. Intimate Experiences of Italian Fifteenth-Century Art, New Haven-London 2014.

Rнову A., The meaning of inscriptions for the early and middle Byzantine culture. Remarks on the interaction of word, image and beholder, [in:] Scrivere e leggere nell' alto Medioevo: Spoleto, 28 aprile - 4 maggio 2011, Spoleto 2012, p. 731-753.

Riccioni S., La Croce in Rosano oltre il Lazio e la Toscana. Riflessi 'europei' della 'riforma gregoriana', [in:] La pittura su tavola del secolo XII. Riconsiderazioni e nuove acquisizioni a seguito del restauro della Croce di Rossano, ed. C. Frosinini, G. Wolf, A. Monciatti, Firenze 2012, p. 119-132.

Riccioni S., Epigrafia, spazio liturgico e Riforma gregoriana, un paradigma: il programma di esposizione grafica di Santa Maria in Cosmedin a Roma, HAM 6, 2000, p. 143-156.

Ross L., Language in the Visual Arts: The Interplay of Text and Imagery, Jefferson 2014.

SAEnger P., Space Between Words: The Origins of Silent Reading, Stanford 2000.

Sandberg Vavalà E., La croce dipinta itaiana e l'iconografia della passione, Verona 1929.

SAntini C., Un'antologia pittorica del primo Trecento nella Chiesa di San Francesco a Udine, ArtC 82/762, 1994, p. 185-198.

Scala G., Le epigrafi, [in:] Lo spazio letterario del Medioevo, vol. 2: La circolazione del testo, ed. G. Cavallo, C. Leonardi, E. Menestò, Roma-Salerno 1994, p. 409-441.

Schmidt V.M., Tavole dipinte. Tipologie, destinazioni e funzioni, [in:] L'arte medievale nel contesto 300-1300. Funzioni, iconografia, techniche, ed. P. PIVA, Milano 2006, p. 205-239.

Scott Brown P., The verse inscription from the deposition relief at Santo Domingo de Silos: word, image, and act in medieval art, JMIS 1/1, 2009, p. 87-111.

Тнову P., Le Crucifix des Origines au Concile de Trente: étude iconographique, Nantes 1959.

Wilkins D.G., Opening the Doors to Devotion: Trecento Triptychs and Suggestions Concerning Images and Domestic Practice in Florence, [in:] Italian Panel Painting of the Duecento and Trecento, ed. V.M. SснміDт, Washington 2001, p. 371-393.

Williamson B., Altarpieces, Liturgy, Devotion, Spe 79/2, 2004, p. 341-406. 


\title{
Web sources
}

http://www.documentacatholicaomnia.eu/04z/z_1100-1200_Auctor_Incertus_Carmen_Paraene ticum_Ad_Rainaldum_MLT.pdf.html [15 IV 2016]

http://marcusmarulus.blogspot.com/2011/06/jthe os-jedan-splitski-srednjovjekovni.html [15 IV 2016]

\begin{abstract}
The paper discusses a group of monumental crucifixes from the $13^{\text {th }}$-century East Adriatic and Italy, pained or executed in low relief, that display a verse inscriptions on the transverse limb of the cross. The main scope of the paper is to examine the provenance of the text inscribed in order to yield clearer insight into their function, use and original location in the church interiors. The paper specifically aims at analyzing three monumental crucifixes from the East-Adriatic city of Zadar which, although have already been the subject of a respectable number of studies, have not attracted attention as objects of devotion. My interest, therefore, is turned towards verse inscription as their distinctive feature and, as I shall argue, a key aspect in understanding their function. Examining the nature of the text displayed, iconography and materiality of these crucifixes, my main argument is to demonstrate how these objects provoked a multi-faced response from their audience, since were experienced by seeing, hearing and touching respectively.
\end{abstract}

Keywords: monumental crucifixes, pained crosses, verse inscriptions, medieval devotional poetry, medieval devotional practices, Zadar.

Matko Matija Marušić

Institute of Art History

Ulica grada Vukovara 63/III

Zagreb, Croatia

matkomatijamarusic@gmail.com 


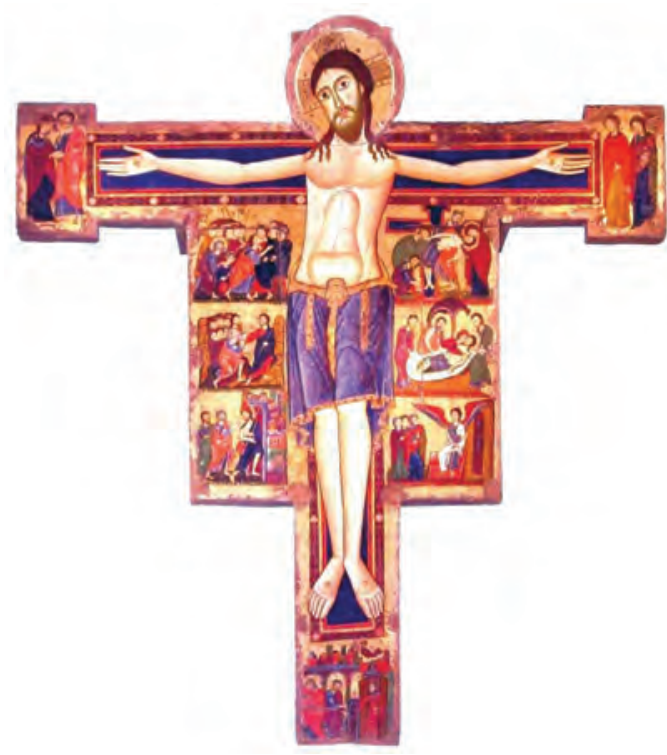

Fig. 1. Unknown master, Painted cross, ca. 1130-1150, Saint Mary's Monastery, Rosano (courtesy of the Ministero per le beni e attività culturali - Opificio delle Pietre Dure, further reproduction prohibited).

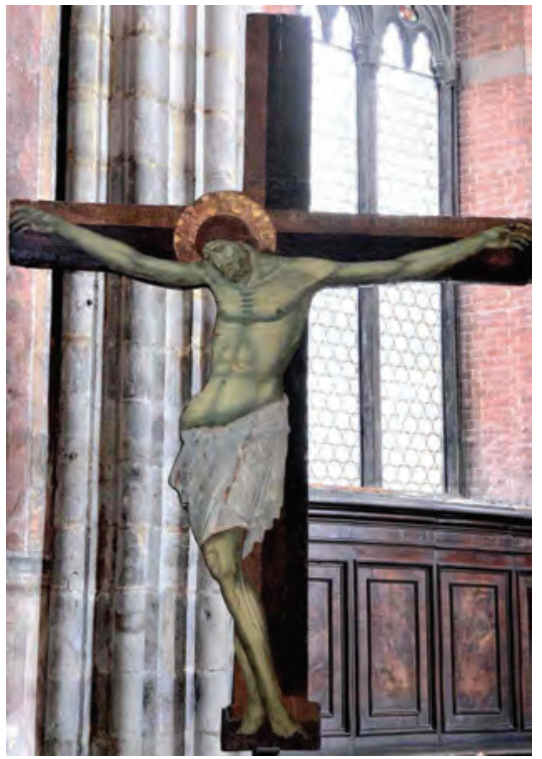

Fig. 2. Maestro della Cappella Dotto (att.), Painted Cross, ca. 1250-1300, Santa Maria Gloriosa dei Frari, Venice (source: C. CoRsato, Public Piety and Private Devotion: The Altar of the Cross, Titian and the Scuola della Passione at the Frari).

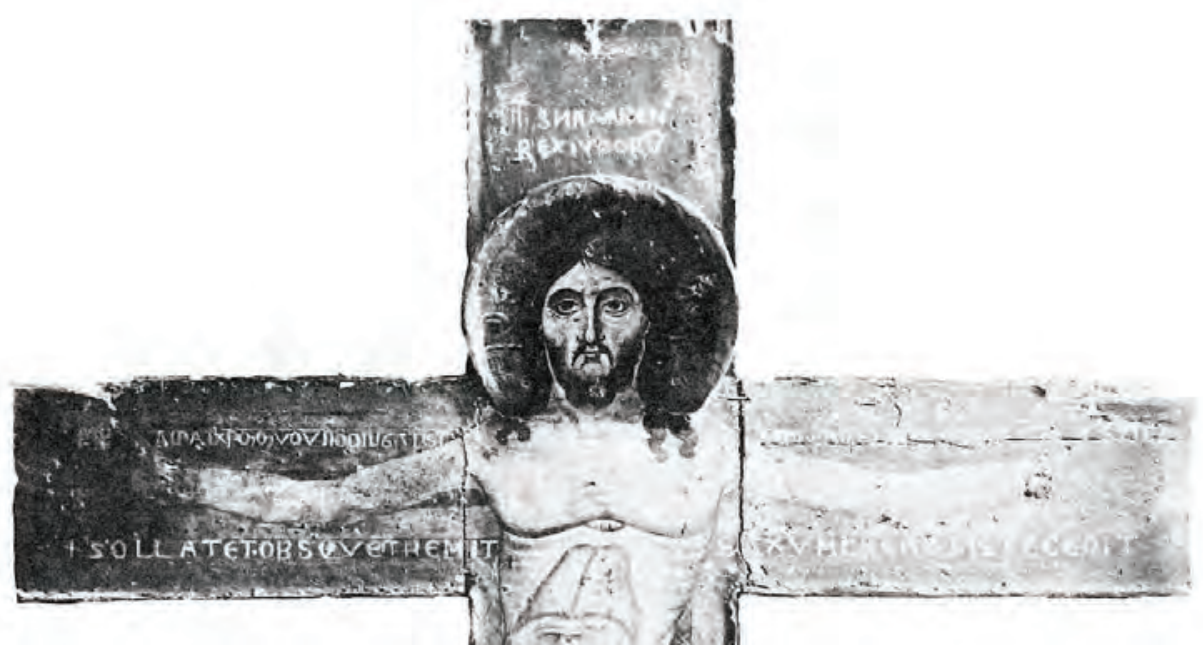

Fig. 3. Unknown master, Painted cross, ca. 1250, formerly at the Saint Mary Nunnery, Zadar (source: G. Gamulin, The painted crucifixes in Croatia). 


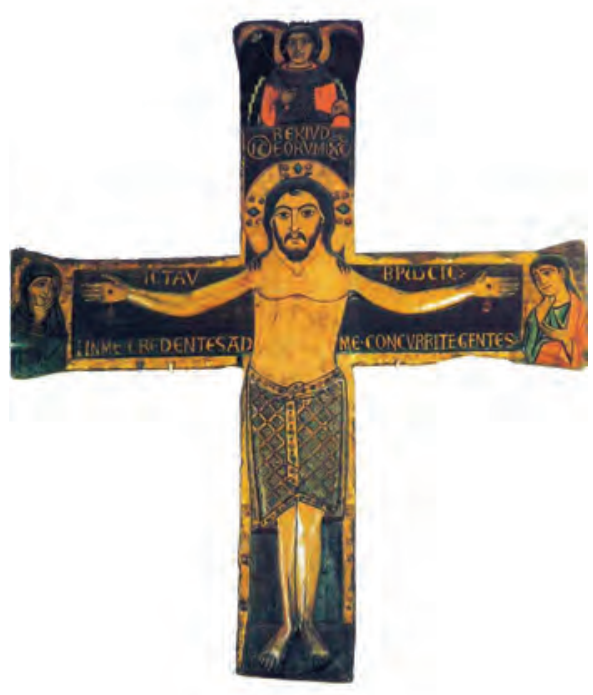

Fig. 4. Unknown master, Crucifix, ca. 11501200, Collection of the Franciscan Friary, Zadar (source: G. Gamulin, The painted crucifixes in Croatia).

Fig. 6. Michele di Baldovino (att.), Painted cross, ca. 1250-1300, San Pietro in Vinculis, Pisa (courtesy of the Soprintendenza delle arti e paesaggio per le province di Pisa e Livorno, further reproduction prohibited).

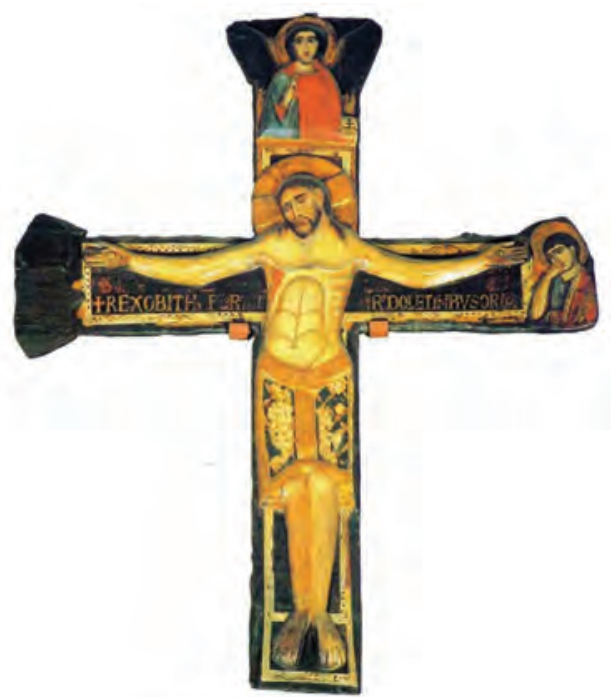

Fig. 5. Unknown master, Crucifix, ca. 1200-1300, Saint Michael church, Zadar (source: G. GAmulin, The painted crucifixes in Croatia).

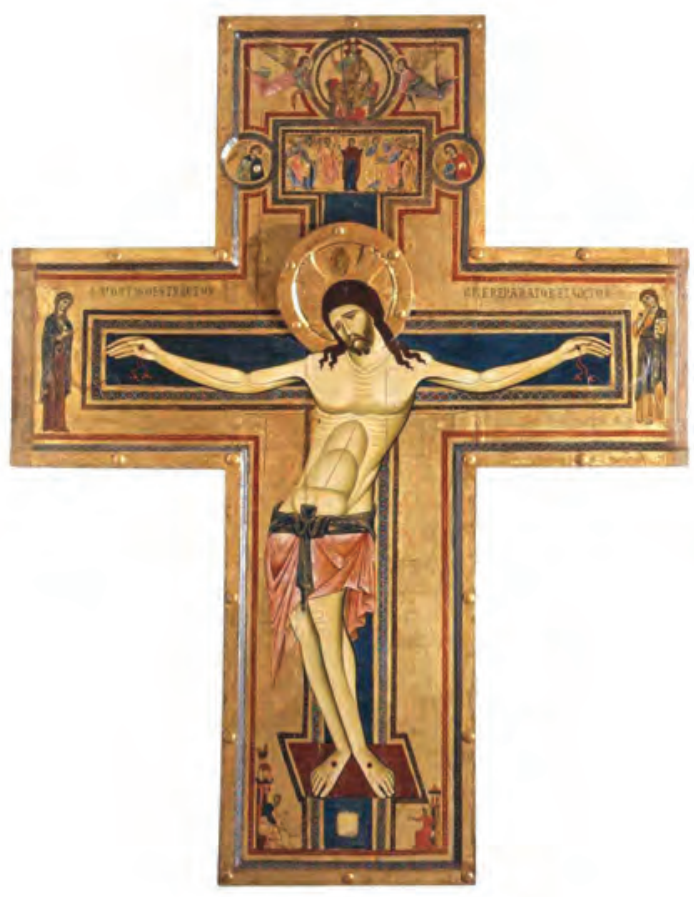

